\title{
ЯЗЫКОЗНАНИЕ
}

UDC 811.113.3

Thórhallur Eythórsson, Ingunn Hreinberg Indriðadóttir University of Iceland

\section{THE PREPOSITIONAL ABSOLUTE CONSTRUCTION IN ICELANDIC}

For citation: Thórhallur Eythórsson, Ingunn Hreinberg Indriðadóttir. The prepositional absolute construction in Icelandic. Scandinavian Philology, 2018, vol. 16, issue 1, pp.3-18. https://doi.org/10.21638/11701/spbu21.2018.101

The Prepositional Absolute Construction (PAC) in Modern Icelandic can be defined as a small clause containing a subject NP and a non-finite verb (a present or past participle) whose case is governed by the preposition að 'at'. Giving a brief historical overview of the PAC in Old Norse, we show how it differs from the construction in Modern Icelandic. In Old Icelandic, both dative and accusative NPs are attested in the PAC whereas in Modern Icelandic only dative NPs are found. Moreover, the distribution of the present and past participles are different in Old and Modern Icelandic. In addition, we discuss analogous constructions in a few related languages, both within Germanic (Gothic, Old High German, Old Frisian and Old English), as well as outside of Germanic (e.g., Latin and Greek). The main emphasis, however, is on a description of the PAC in Modern Icelandic based on a detailed web study of the relevant constructions. This method was chosen because it was found to be the best way to demonstrate the fact that the PAC is relatively commonly used in Modern Icelandic, both in formal and informal language situations. Most of the examples presented in this connection are from the web study, and others were reviewed by a small number of speakers in an informal acceptability study. Among the issues considered is the syntactic function of the small clause, the valency of the verbs in the PAC and the possible word order patterns within the construction.

Keywords: Modern Icelandic, Old Norse, Gothic, Old High German, Old Frisian, Old English, Prepositional Absolute Construction, small clause, valency, government, accusative, dative, word order pattern. 


\section{INTRODUCTION}

In this paper we present an analysis of a syntactic construction in Icelandic which we term the Prepositional Absolute Construction (PAC). There are two main types of this construction, the second comprising two subtypes. Type 1 involves a construction with the present participle and Type 2 contains the past participle.

- Type 1: að öllum sjáandi 'while everybody sees/saw'

- Type 2a: að viku liðinni 'when the week is gone/was gone'

- Type 2b: að athuguðu máli 'when the matter has/had been considered', i.e. 'when someone has/had considered the matter'

The PAC consists of the preposition að 'at' taking an NP complement, modified by a verb in the present or past participle in adjectival function. In Modern Icelandic the NP is in dative case, but in Old Icelandic an accusative NP also occurs with the past participle but not with the present participle. The past participle shows full agreement (case, number and gender) with the NP in Old and Modern Icelandic. The present participle, on the other hand, is not inflected in Modern Icelandic, but it shows agreement in Old Icelandic, with a distinction in the masculine singular (OIc. komandi 'coming' (nom.sg.)/komanda (obl.sg.) vs. Modern Icelandic komandi (nom./obl.sg.)).

The grammatical function of the NP in the PAC is either that of a subject of a finite active clause (Type 1 and Type $2 \mathrm{a}$ ) or a subject of a finite passive clause, i.e. an "underlying" object (Type 2b).

$\begin{array}{lll}\text { (1a) } \begin{array}{l}\text { Allir } \\ \text { everybody }\end{array} & \begin{array}{l}\text { sjá } \\ \text { sees }\end{array} & \begin{array}{l}\text { petta. } \\ \text { this }\end{array} \\ \text { (1b) } & \begin{array}{l}\text { Vikan } \\ \text { the week }\end{array} & \text { líður. } \\ \text { passes }\end{array}$

Due to their correspondence to subjects in finite clauses, in this paper we call the NPs in PACs "subjects". However, it is unclear that it be shown independently, by means of the standard tests for subjecthood, that the relevant oblique NP is actually a subject in the PAC. The word order in the PAC is either verb-subject or subject-verb; the latter 
appears obligatory if the NP is a pronoun, e.g. at honum liðnum (at him passed) 'when he is dead'.

The syntactic function of the PAC is that of an adverbial subordinate clause, more precisely a temporal clause (as indicated by the gloss/ translation 'when, while, after' in the examples above).

'Bjarni robbed the bank while everybody saw.'

$\begin{array}{llll}\text { (2b) Komdu aftur } & \text { að } & \text { liðnu } & \text { sumri. } \\ \text { Come back } & \text { at } & \text { passed } & \text { summer }\end{array}$

'Come back when the summer has passed.'

(2c) Við tökum ákvörðun að athuguðu máli. We take decision at considered matter

'We will make a decision when the matter has been considered.'

The PAC itself is indifferent with respect to tense (as suggested by the translation '...is/was...'); the temporal relation is determined by the tense of the verb in the matrix clause.

In this article we present an analysis of the PAC in Modern Icelandic, which we define as a small clause. In section 2 we give a brief historical overview of the PAC in Old Norse and how it differs from the construction in Modern Icelandic. In section 3 we describe analogous constructions in a few related languages, both within and outside of Germanic. In section 4 we describe the PAC in Modern Icelandic based on a detailed web study of the constructions. We chose this method because we found it the best way to demonstrate that the PAC is relatively commonly used in Modern Icelandic, both in formal and informal language situations. Most of the examples presented in this section are from the web study and others were reviewed by a small number of speakers in an informal acceptability study. We then consider the possible word order within the $\mathrm{PAC}$ and present an analysis of the construction. In section 5 we give a few concluding words.

\section{OLD NORSE}

Types 1 and 2 of the PAC occur in Old Norse, i.e. Old Icelandic and Old Norwegian (these languages form the West Norse branch of North Germanic). The present participle is only attested with dative NPs, 
whereas the past participles occur with both accusative and dative NPs. The preposition at in Old Norse is the same word as að in Modern Icelandic. Some examples are given below (taken from [Nygaard, 1905]; cf. also [Eythorsson, 1995, 1997]). As mentioned, the present participle shows different inflectional endings in the nominative singular as against other oblique cases of the masculine singular (e.g., komandi vetr 'coming winter (nom.sg.)' vs. komanda vetri 'coming winter (dat.sg.)').

$\begin{array}{lll}\text { (3a) at upprennandi sólu } \\ \text { at upcoming } & \text { sun }\end{array}$

'when the sun is/was coming up' (Hárbarðsljóð 58)

(3b) at uppvesandi sólu

at upbeing sun

'when the sun is/was up' (Gulapingslög 266)

(3c) at komanda vetri

at coming winter

'when the winter is/was coming' (Konungsskuggsjá 9)

$\begin{array}{lll}\text { (3d) at mér } & \text { lifanda } \\ \text { at me } & \text { living }\end{array}$

'while I am living' (Pr 197, Nygaard 1905)

$\begin{array}{lllll}\text { (3e) Ef } & \text { maðr } & \text { er veginn } & \text { i } & \text { öldrhúsi } \\ \text { if } & \text { man } & \text { is killed } & \text { in } & \text { tavern }\end{array}$

at brennanda eldi eða í dags ljósi. at burning fire or in day light

'If one is killed in a tavern while (the) fire burns or in daylight'.

(Gulapingslög 157)

The past participle agrees with the co-occurring NP in case, number and gender. In the examples below it agrees with a dative in feminine singular and masculine plural, respectively.

$\begin{array}{lll}\text { (4a) at upprunninni sólu } \\ \text { at upcome } & \text { sun }\end{array}$

'when the sun is/was up' (Homily 82)

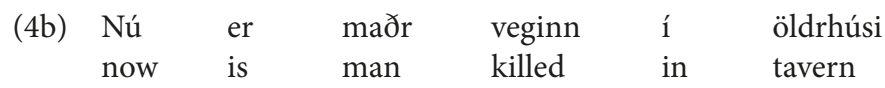


$\begin{array}{ll}\text { at } & \text { slokknum eldum. } \\ \text { at } & \text { extinguished }\end{array}$

'Now one is killed in a tavern when the fires have been extinguished'.

(Gulapingslög 157)

In addition, the PAC with a dative and past participle is common in fixed expressions, e.g. at svá göru ('having done so'), at svá búnu ('having done so'), at svá moeltu ('having said so'). These expressions are still found in Modern Icelandic, and at least the latter two are quite common in colloquial speech (að svo búnu, að svo moeltu).

The examples in (5) show the past participle agreeing with an NP in the accusative. This construction appears to be very rare, even within Old Norse, with only a few examples of an accusative being attested in the Poetic Edda; thus, this is an instance of very archaic Old Norse.

$\begin{array}{lll}\text { (5a) at liðinn } & \text { fylki } \\ \text { at } & \text { passed } & \text { king }\end{array}$

'when the king is/was dead' (Helga kviða Hjörvarðssonar 42)

(5b) at pinn föður dauðan... at jöfr fallinn at your father dead at king slain 'when your father is/was dead...the king is/was slain' (Guðrúnarkviða II 25)

The PAC has been regarded as an example of "Learned Style" in Old Norse [Nygaard, 1896, 1905]; (see also [Hauksson, Oskarsson, 1994]). Arguments for this position include that fact that the construction is found in texts that arguably do not belong to the Norse literary tradition, but are rather influenced by foreign, especially Latin, learning (dealing, e.g., with religious and scholarly subjects). The idea would then be that the emergence of the construction was somehow triggered by the absolute ablative construction in Latin (see section 3 below).

(6) at týjanda guði at helping God 'when God is helping' (Homily 55, 13)

However, this construction also occurs in texts which are not otherwise typical of Learned Style, e.g. the Edda, native law texts, and historical texts like Heimskringla. 

(7) at hann vill kvángast at lifandi dróttningunni that he wants get married at living the queen 'that he wants to get married while the queen is alive' (Heimskringla $700,31)$

Therefore, the PAC must be considered "native" Old Norse [Eythórsson 1995, 1997], although its use may have been reinforced, as it were, in translations from Latin and texts written under the influence of that language. It may be noted that there are also rare cases of absolute constructions without a preposition, in particular in Old Norse religious texts. The lack of preposition in these structures is a sign that they are highly likely to be modelled on Latin absolute constructions.

(8) pá má hvárki peira sér til forræði leita báðum peim lifandum then may neither their self to custody seek both them living 'then neither of them may look for custody for themselves when they are both living' (Eids. 22, Nygaard 1905)

Interesting though the PAC may be, it has not received much attention in recent work on Old Norse syntax. Thus, for example, there is no mention of it at all in Faarlund's (2005) syntax of Old Norse. The same goes for Rögnvaldsson's (2005) survey of syntactic change in the history of Icelandic. Admittedly PAC is not a core syntactic phenomenon in Old Norse-Icelandic; it is clear, however, that no description of the language is complete without a discussion of this construction. For a concise description of this phenomenon, see Nygaard (1905), as well as a first attempt at an analysis in Eythórsson $(1995,1997)$.

\section{ANALOGUES IN RELATED LANGUAGES}

First, very briefly, there are absolute constructions occurring with participles, mostly without a preposition, in the older Indo-European languages, e.g. Latin (ablative absolute), Ancient Greek (genitive absolute), Old Church Slavonic (dative absolute) and Vedic/Sanskrit locative absolute. Just like in Old Norse the participle agrees with the NP (cf. the Latin term participium coniunctum or agreeing participle). The following examples are from Latin and Greek (see [Eythorsson, 1995]).

$\begin{array}{lll}\text { (9a) sole } & \text { oriente } \\ \text { sun } & \text { rising }\end{array}$


(9b) heliou anateilontos
sun

'when the sun is/was rising'

There are however also constructions in the archaic Indo-European languages containing a preposition, including the " $a b$ urbe condita construction" in Latin, which has analogues in other Indo-European languages, notably Ancient Greek. Although semantically somewhat different from the PAC in Old Norse (and prepositionless analogues in other languages), this construction is remarkable due to the fact that a preposition (Latin $a b$ 'from') governs an NP in the ablative and an agreeing past participle (urbe condita '(lit.) the city founded').
(10) $\mathrm{ab}$
urbe
condita
from city
founded
'from the founding of the city'

In addition to Old Norse, the PAC is also found in other Old Germanic languages, Gothic (East Germanic) and Old High German, Old Frisian and Old English (West Germanic). Moreover, there are parallels in other archaic Indo-European languages, both with and without a preposition.

Strikingly, Gothic has an exact parallel to Type 1, with the present participle being introduced by the preposition at 'at' (which is etymologically of course the same element as preposition at in Old Norse and að in Modern Icelandic). This structure is attested both with dative and accusative. Note that the past participle is not attested in the PAC in Gothic. The following examples involve the construction with a dative NP.
(11) at sunnin pan urrinnandin
at the sun then upcoming
'when the sun was coming up' (Mark 4:6)
(12) at urrinnandin sunnin
at upcoming sun
'when the sun was coming up' (Mark 16:2)
(13) at wisandin kindina Swriais Kureinaiau at being governor Syria Cyrenius
'when Cyrenius was governor of Syria' (Luke 2:2) 
There is one attestation of PAC in Gothic containing an accusative $\mathrm{NP}$ with a present participle.
(14)

$\begin{array}{ll}\text { at } \quad \text { maurgin pan } & \text { waurbanana } \\ \text { at } \quad \text { morning then } & \text { becoming } \\ \text { 'when morning was coming' (Matthew 27:1) }\end{array}$

Although the PAC is used to translate a comparable construction in Greek, the genitive absolute, the presence of the preposition, as well as the parallel in Old Norse-Icelandic, reveals that the construction must be indigenous to Gothic. Hence the PAC must at least be a real NorthEast Germanic inheritance in Old Norse-Icelandic and Gothic.

On the other hand, there are no examples of Type 2 with a past participle attested in in Gothic. This means either that Old Norse has innovated this type, or that Gothic has lost a construction that it used to have earlier. Given parallels containing the past participle in other languages (e.g. Latin and Greek), the second possibility seems more likely.

Moreover, the Old West-Germanic languages, Old High German (OHG), Old Frisian (OFris) and Old English (OE), have the same construction but use a different preposition (be/bi 'by, at, with...'). Evidently only present participles with dative NPs are attested in Old West-Germanic (cf. [Eythorsson, 1995], citing [Behaghel, 1928]).

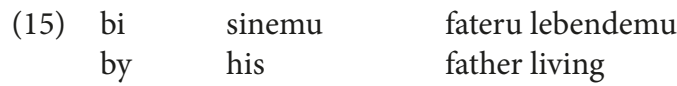
'when his father was living' (OHG)
$\begin{array}{lll}\text { (16) bi slepandere thiade } \\ \text { by sleeping } & \text { people }\end{array}$
'when the people were sleeping' (OFris)
(17) be pe lifigendum
by you living
'when you were living' (OE)

The fact that Old Norse-Icelandic and Gothic coincide in the use of at/að in the PAC, whereas Old West Germanic has a different lexical item $(b e / b i)$, is an interesting detail which may be of importance for the dialectal grouping of the Old Germanic languages. 
As in Old Norse, in the other Old Germanic languages there are also examples of absolute constructions without a preposition. Again, these are very probably due to foreign influence, either Greek (in the case of Gothic) or Latin (in the case of West Germanic).

\section{MODERN ICELANDIC}

As stated above, the PAC exists in Modern Icelandic, just as in Old Norse, although its distribution has changed. First, there are very few occurrences of the present participle in the PAC, but the past participle is relatively common, and can even be said to enjoy a certain productivity. Second, only the dative occurs in this construction, both with the present and past participles, whereas the accusative, which used to be able to occur with the past participle, has disappeared. As in Old Norse, the PAC has not received much attention in linguistic work on Modern Icelandic; for example, there is no discussion of it in Thráinsson's (2007) monumental handbook of Icelandic syntax.

\subsection{Type 1}

The PAC of Type 1 involves an active present participle, which can be an intransitive verb (18a) or a transitive verb (18b).

\begin{tabular}{|c|c|c|c|c|c|}
\hline $\begin{array}{l}\text {...garðar, } \\
\text { gardens }\end{array}$ & $\begin{array}{l}\text { með } \\
\text { with }\end{array}$ & $\begin{array}{l}\text { trjágróðri } \\
\text { silva }\end{array}$ & $\begin{array}{l}\text { og } \\
\text { and }\end{array}$ & $\begin{array}{l}\text { runnum, } \\
\text { shrubs }\end{array}$ & \\
\hline par sem & gnægð & er & berja & аð & líðandi sumri. ${ }^{1}$ \\
\hline where & abundance & is & berries & at & passing summer \\
\hline
\end{tabular}

$\begin{array}{llllll}\text { Var } & \text { hann fluttur } & \text { út... } & & \\ \text { was } & \text { he } & \text { moved } & \text { out } & & \\ \text { að } & \text { öllum sjáandi á } & \text { strætinu } & \text { fyrir } & \text { framan. }{ }^{2} \\ \text { at } & \text { everybody } & \text { seeing } & \text { on } & \text { street } \\ \text { for } & \text { front } & & & \end{array}$

'He was moved out... while everybody saw in the street out front.'

\footnotetext{
${ }^{1}$ Article. Náttúrufroðingurinn. $5^{\text {th }}$ ed. 01.04.1935. (http://timarit.is/view_page_ init.jsp?pageId=4263464)

2 Article. Vísir 25.10.1963.

(http://timarit.is/view_page_init.jsp?issId=182815\&lang=gl)
} 
Although this construction is possible with transitive participles, which are actually more common in this structure than intransitive verbs, it does not allow the object to be included in the structure, as seen by the contrast between (20a) and (20b).

(20a) Nemandinn svindlaði á prófinu aðkennaranum vitandi. the student cheated on the exam at the teacher knowing 'The student cheated on the exam while the teacher knew.'

(20b)

$\begin{array}{llll}\begin{array}{l}{ }^{*} \text { Nemandinn } \\ \text { the student }\end{array} & \begin{array}{l}\text { svindlaði } \\ \text { cheated }\end{array} & \text { á } & \text { prófinu } \\ \text { að kennaranum } & \text { vitandi } & \text { pað. } & \\ \text { at the teacher } & \text { knowing } & \text { that } & \end{array}$

'The student cheated on the exam while the teacher knew that.'

This means that the construction is only possible with intransitive verbs and with transitive verbs used intransitively. Thus, the construction itself is intransitive in nature.

As mentioned, Type 1 is not very common in Modern Icelandic and has limited function, as it only allows verbs that have theme and experiencer subjects, such as the verbs in examples (1) and (2) above.

There are a few verbs that only appear in the present participial form, for example the prefixed participles fjarverandi ('absent'), viðverandi ('present'), and ásjáandi ('onlooking'). In other words, outside the present participle, there are no verbs such as ${ }^{*}$ fjarvera ('be absent'), *viðvera ('be present'), and ‘ásjá ('onlook'). Interestingly such participles can also occur in the PAC, as in the examples in (21).
$\begin{array}{lllll}\text { (21a) } & \ldots \text { svo } & \text { undarlega } & \text { vill hann hallast, } \\ \text { so } & \text { strangely } & \text { will he lean }\end{array}$ pegar um hann er ráðið aðokkur fjarverandi. ${ }^{3}$ when about him is decided at us absent 'so strangely it will lean when it is decided upon while we are absent.'

(21b)

$\begin{array}{llllllll}\text {... að } & \text { blanda } & \text { mér } & \text { fyrst } & \text { í } & \text { pá } & \text { umræðu } & \text { núna } \\ \text { to } & \text { involve } & \text { me } & \text { first } & \text { in } & \text { that } & \text { discussion } & \text { now } \\ \text { að } & \text { honum } & \text { viðverandi. }{ }^{4} & & & & \end{array}$

${ }^{3}$ Article. Vikublaðið. 07.04.1995. (http://timarit.is/view_page_init.jsp?pageId=3638718)

${ }^{4}$ Speech in Parliament. 18.03.2016. (https://www.althingi.is/altext/raeda/145/ $\operatorname{rad} 20160318 \mathrm{~T} 143442 . \mathrm{html})$ 
at him present

'...to involve myself in this discussion now while he is present.'

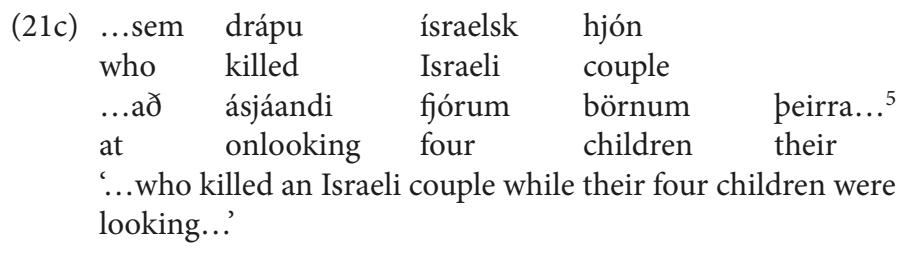

As the participles have adjectival function, they can in most cases also appear as attributes (22) and verb complements in predicate constructions (23).
(22)
$\begin{array}{lll}\text { Ásjáandi } & \text { börn } & \text { hágrátandi. }^{6} \\ \text { onlooking } & \text { children } & \text { blubbering }\end{array}$
'Onlooking children blubbering.'
(23) Brotist inn á meðan íbúar voru fjarverandi í páskafríi. broken into while inhabitants were absent in Easter leave 'Burgled while inhabitants were absent on Easter leave.'

\subsection{Type 2}

As we have shown, Type 2 comprises two subtypes. The past participles of Type $2 \mathrm{a}$ are formed from intransitive verbs and this construction is always active. In Modern Icelandic the participles that can occur in this type include liða 'pass', koma 'come', fara 'go' and deyja 'die.' The verbs of this type are intransitives with the meaning change (of location or state) involving theme and patient subjects.
(24a) Peir félagar lögðu af stað að liðinni fullbirtu. ${ }^{7}$ they companions set off place at passed full light 'The companions set off when full daylight had gone.'

5 Blogpost. 26.10.2015. (https://jonvalurjensson.blog.is/blog/jonvalurjensson/ entry/1741826/http://jonvalurjensson.blog.is/blog/jonvalurjensson/entry/2111163/)

6 Article. Pressan. 07.09.2011. (http://www.pressan.is/frettir/lesafrett/budarhnupltharf-thrja-fullordna-karlmenn-til-ad-halda-einni-unglingsstelpu---asjandi-bornhagratandi)

${ }^{7}$ Blogpost 01.10.2015. (https://bardastrondblog.wordpress.com/2015/10/01/ganga-yfir-kleifaheidi/) 
(24b) Аð honum komnum verða fjórir nýlegir at him come will be four newish og góðir bátar hér á Patreksfirði. ${ }^{8}$ and good boats here on Patreksfiörour 'When it has arrived there will be four newish and good boats here in Patreksfjörður.'

(24c) Раð fer vagn kl. 10:03 en að honum förnum there goes bus hr. 10:03 but at him gone parf að bíða í heilar 4 klukkustundir... ${ }^{9}$ need to wait in whole 4 hours 'A bus goes at 10:03 but when it has gone one needs to wait four whole hours.'

(24d) $\begin{array}{llll}\ldots \text { og vona } & \text { að } & \text { mér } & \text { dánum, } \\ \text { and hope } & \text { at } & \text { me } & \text { dead }\end{array}$ að verk mín verði pjóðinni til skemmtunar. ${ }^{10}$ that work mine will be the nation for entertainment '....and (I) hope that when I am dead, my work will entertain the nation.'

The past participles of Type $2 b$ involve passives of transitive verbs.

(25a) ...og á erfitt með að slíta sig
and has difficulty with to tear himself thence
fyrr en að lesinni síðustu blaðsíðu. ${ }^{11}$
until at read last
'...and struggles to tear himself from there until he has read the last
page.'

${ }^{8}$ Article. Tíminn. 04.09.1960. (http://timarit.is/view_page_init.jsp?pageId= 1041912)

${ }^{9}$ Article. Morgunblaðið. 12.10.2010. (https://www.mbl.is/greinasafn/grein/ $1352187 /)$

${ }^{10}$ Matthías Johannessen. 1999. Við Kárahnjúka og önnur kennileiti - Helgispjall. Árvakur hf. Reykjavík.

${ }^{11}$ Article. Visir. 28.06.2014. (http://www.visir.is/g/2014706289943/stulkurnar-fraromonsku-ameriku-hafa-vinninginn) 
(25b) Ég er sammála pví, að fenginni mikilli reynslu... I am agreed that at had much experience ... að innilokun í fangelsi er vond. ${ }^{12}$ that confinement in jail is bad 'I agree with that, having had much experience, that confinement in jail is bad.'

It seems to be a condition for Type $2 \mathrm{~b}$ that the underlying agent of the PAC is identical to the agent in corresponding matrix clause. This can be seen by the contrast in (26). In (26a) the agent is identical in both clauses, and the example is grammatical. In (26b), on the other hand, the underlying agent of the PAC is different from the agent of the matrix clause, and the sentence is not felicitous, if not outright ungrammatical.

(26a) Аð málinu athuguðu var nemandinn felldur á prófinu. at the matter considered was the student flunked on the exam 'When the matter had been considered, the student was flunked on the exam.'

(26b) *Að málinu athuguðu féll nemandinn á prófinu. at matter considered flunked the student on the exam Intended meaning: 'When the matter had been considered, the student flunked on the exam.'

Moreover, at least some speakers we have consulted find it possible to include the agent in the PAC clause, as in (27), although many speakers would not find such sentences felicitous (the \% sign here represents variation in speakers' acceptance of this sentence.)

\begin{tabular}{|c|c|c|c|c|}
\hline $\begin{array}{l}\text { (27) } \\
\text { \%Аð } \\
\text { at } \\
\text { var } \\
\text { was }\end{array}$ & $\begin{array}{l}\text { málinu } \\
\text { the matter } \\
\text { nemandinn } \\
\text { the student }\end{array}$ & $\begin{array}{l}\text { athuguðu } \\
\text { considered } \\
\text { felldur } \\
\text { flunked }\end{array}$ & $\begin{array}{l}\text { af } \\
\text { by } \\
\text { á } \\
\text { on }\end{array}$ & $\begin{array}{l}\text { kennaranum } \\
\text { the teacher } \\
\text { prófinu } \\
\text { the exam }\end{array}$ \\
\hline
\end{tabular}

'When the matter had been considered by the teacher, the student was flunked on the exam'

As mentioned at the outset, the grammatical function of the NP in the PAC corresponds either that of a subject of a finite active clause (Type 1 and Type 2a) or a subject of a finite passive clause (Type 2b). The participle looks like an adjective modifying the NP, but its syntactic

${ }^{12}$ Article. Visir. 07.01.2016. (http://www.visir.is/g/2016160109173/-vid-eigumekki-ad-taka-mid-af-einhverjum-brjaludum-bloggurum-) 
behaviour is different from an adjective. This can be demonstrated in a straightforward way by pointing out that ordinary adjectives cannot figure in the PAC.

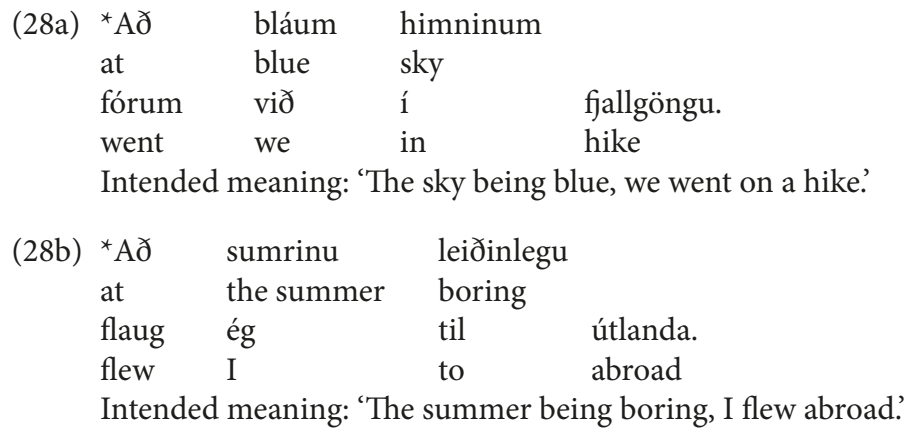

In addition, the fact that the PAC us used as a temporal clause shows that the participle has a verbal function. Therefore, we propose that the NP and the participle together form a "small clause" (SC), consisting of a subject NP and a non-finite verb. The case of the NP and the participle is governed by the preposition að, which is a case assigner but not a temporal conjunction (a complementizer). Thus, the PAC corresponds to structures in other Indo-European languages which are not introduced by a preposition, like the absolute ablative in Latin and similar constructions elsewhere.

\section{CONCLUSION}

Although the Prepositional Absolute Construction (PAC) has never been very widely attested in Icelandic through its history, it is found already in Old Norse and has survived to this day, still thriving in Modern Icelandic, both in formal and informal language situations. The PAC functions syntactically as a temporal clause and can be analysed as a small clause, consisting as it does of a subject and a non-finite verb. True, Type 1, involving the present participle, is very restricted, being confined to rather few intransitive verbs and transitive verbs used intransitively. By contrast, Type 2 - both the active Type $2 \mathrm{a}$ and the passive Type $2 \mathrm{~b}$ - is more common; it is mostly found in formal registers, but also not absent from informal registers, for example blogposts. It is not unexpected, however, that the PAC is generally associated with formal 
speech as speakers are likely to recognize old expressions such as að svo moeltu 'when this had been said' as formal. Consequently, speakers may conclude that the PAC is generally characteristic of formal language.

Type 2 seems to enjoy a certain productivity in Modern Icelandic as can be seen from the fact that a number of verbs are being used in the construction that did not occur in it previously. This does not necessarily mean that the productivity of the construction is a new development. Examples of the PAC are not very easily found in neither Old Norse nor Modern Icelandic, which suggests that the construction has never been highly active in the language. It could well be, however, that this type of the PAC has always been productive, allowing various verbs within the restrictions described in section 4 , although it never became very common.

It is interesting that only the dative occurs in the PAC in Modern Icelandic, and not the accusative. In fact, the demise of the accusative in this construction (Type $2 \mathrm{a}$ ) is a very old phenomenon, since the only examples of an accusative in PACs are attested in the Poetic Edda (see section 2). It is possible that the dative ousted the accusative early on because the dative was considered the "unmarked" oblique case in absolute constructions. Possibly, this development was influenced by Learned Style, which would have meant that the generalization of the dative was, at least indirectly, triggered by translations from Latin.

\section{REFERENCES}

Behaghel O. Deutsche Syntax, eine geschichtliche Darstellung. III. Die Satzgebilde. Heidelberg: Winter, 1928.

Eythórsson Th. Verbal Syntax in the Early Germanic Languages. PhD disseration. Cornell University, 1995.

Eythórsson,Th. „Að upprennandi sólu.“ Stílfræði eða setningafræði? Anna Agnarsdóttir, Pétur Pétursson and Torfi H.Tulinius., eds., Milli mála. Maður, guð og menning í hnotskurn hugvísinda, pp.369-376. Reykjavík: Háskólaútgáfan, 1997.

Faarlund J.T. The Syntax of Old Norse. Oxford: Oxford University Press, 2005.

Hauksson, Thorleifur and Thórir Óskarsson. Íslensk stílfræði. Reykjavík: Mál og menning, 1994.

Nygaard M. Norrøn syntax. Oslo: 1905. Aschehoug.

Rögnvaldsson E. Setningafræðilegar breytingar í íslensku. Höskuldur Práinsson, ed., Íslensk tunga III, pp. 602- 635. Reykjavík: 2005. s. 602-635.

Thráinsson $\mathrm{H}$. The syntax of Icelandic. Cambridge: Cambridge University Press, 2007. $576 \mathrm{p}$. 


\title{
Торхаллур Эйтоурссон, Ингунн Хрейнберг Индридадоухтир
}

Исландский университет

\section{АБСОЛЮТНАЯ ПРЕДЛОЖНАЯ КОНСТРУКЦИЯ В ИСЛАНДСКОМ ЯЗЫКЕ}

Для цитирования: Thórhallur Eythórsson, Ingunn Hreinberg Indriðadóttir. The prepositional absolute construction in Icelandic // Скандинавская филология. 2018. Т. 16. Вып. 1. С. 3-18. https://doi.org/10.21638/11701/spbu21.2018.101

Абсолютную предложную конструкцию (АПК) в современном исландском языке можно определить как «предикативный оборот» с подлежащим, выраженным именной группой, и нефинитной формой глагола (причастие настоящего и прошедшего времени), где падежное управление зависит от предлога $а$ ð. В древнеисландском засвидетельствованы АПК, содержащие именные группы как с винительным, так и с дательным падежом, тогда как в современном исландском языке в них возможен только дательный падеж. Кроме того, современный исландский язык отличается от древнеисландского распределением действительных и страдательных причастий. Аналогичные конструкции обсуждаются на примерах родственных языков, как германских (готский, древнефризский и древнеанглийский), так и прочих древних индоевропейских языков (латынь, греческий). Материал для исследования АПК в современном исландском языке брался из Интернета, что позволило определить относительную частотность ее употребления в различных ситуациях общения (формальное, неформальное). Приемлемость употребления АПК в ситуациях неформального общения проверялась на носителях языка. Круг рассматриваемых вопросов включает также синтаксическую функцию оборота, валентность глагола в составе АПК и возможные модели порядка слов в пределах словосочетания.

Ключевые слова: современный исландский язык, древнеисландский, готский, древнефризский, древнеанглийский, абсолютная предложная конструкция, предикативный оборот, валентность, предложное управление, винительный падеж, дательный падеж, модель порядка слов.

\section{Pórhallur Eypórsson}

Professor,

Faculty of Languages and Cultures, University of Iceland,

Sæmundargötu 2,

101 Reykjavík

E-mail: tolli@hi.is

\author{
Ingunn Hreinberg Indriðadóttir \\ Doctoral Graduate Student, \\ Institute of Linguistics, University of Iceland, \\ Sæmundargötu 2, \\ 101 Reykjavík \\ E-mail: ihreinberg@gmail.com
}

Received: 02.03.2018

Accepted: 30.03.2018 